\title{
The Effect of Nostalgia Proneness on Ad-Evoked Nostalgia, Brand Attitude and Purchase Intention
}

\author{
Şeniz Özhan1 ๑, Duygu Talih Akkaya2 $\odot$
}

\begin{abstract}
Nostalgia is generally defined as a longing for the past, and from a marketing perspective it can be described as an emotion that drives the purchase behaviors of consumers. Companies have started to make use of the element of nostalgia in their marketing strategies more frequently in order to be more successful than their competitors in today's intensely competitive market. The aim of the study is to examine the effect of nostalgia proneness on ad-evoked nostalgia, attitude and purchase intention as well as to evaluate it with regard to the purchase decision making process of the consumer. The structural equation model was used for testing the developed hypothesis with a sample group comprised of 381 consumers. The study puts forth that sense of nostalgia has a strong effect on ad-evoked nostalgia, attitude and purchase intention. The findings of the study point out to the marketers that nostalgic signs in advertisements may have positive effects on the brand attitude and the purchase intention of the targeted groups.
\end{abstract}

Keywords

Nostalgia Proneness, Nostalgic Advertisements, Ad-evoked Nostalgia, Brand Attitude, Purchase Intention

\section{The Influence of Nostalgia Proneness on Ad-Evoked Nostalgia, Brand Attitude and Purchase Intention}

The primary role of advertisement in marketing is to convey a message related with a product or service to target consumers. In addition, advertisers try to design messages that will attract the attention of consumers or enable them to stand against the strength of their rivals in the market due to the intensive competition in the fields of many products and services. A striking method that advertisers use is nostalgia described as "longing for the past" which is a type of retro marketing. Even though the term nostalgia has been present for centuries, it can be stated that the inclusion of themes of nostalgia in advertisements has increased in recent years.

1 Corresponding author: Şeniz Özhan (Asst. Prof. Dr.), Tekirdag Namık Kemal University, Çorlu Vocational School, Tekirdag, Turkey. E-mail: serdem@nku.edu.tr ORCID: 0000-0003-3898-8192

2 Duygu Talih Akkaya (Asst. Prof. Dr.), Yalova University, Yalova Vocational School, Yalova, Turkey. E-mail: duygutalih@gmail.com ORCID: 0000-0002-7514-8347

To cite this article: Ozhan, S., \& Talih-Akkaya, D. (2020). The Effect of Nostalgia Proneness on Ad-Evoked Nostalgia, Brand Attitude and Purchase Intention. Istanbul Business Research, 49(2), 380-396. http://doi.org/10.26650/ibr.2020.49.0050 
It is observed that nostalgia in marketing has transformed into an enchanting and distant nostalgic emotion created by marketers to be perceived by consumers. Nostalgia marketing plays a major role in marketing communication since it is related with the emotions of consumers. Recent studies put forth that nostalgia marketing has made positive impacts on consumer behaviors (Nathasia and Nasution, 2016). There are also studies indicating that the styles that were popular during the youth of consumers may affect their preferences throughout their lives (Holbrook and Schindler 1989; 1994; 1996). Thus, when used properly, nostalgia marketing as a new marketing tool may not only provide significant income to a business but also make important contributions in establishing and sustaining a consistent, loyal consumer base.

It is possible to state that nostalgia for marketers serves as a tool to ascribe a nostalgic meaning to products and to satisfy the spiritual needs as well as the longings of modern consumers. The key element in nostalgia marketing is to expose consumers to the product itself or a nostalgic marketing message thereby revealing positive emotions that enable them to mentally return to past experiences. Nostalgic advertisement creates positive emotions of the past and connects these emotions to the advertised brands (Ju et al., 2016).

Even though it can be dated back to the mid-seventeenth century, the use of nostalgia in marketing is still new (Lefi and Gharbi, 2011). The fact that nostalgia as a reaction that is difficult to be estimated by marketers is a combination of positive and negative emotions means that the general emotional value of a nostalgic event may be ambiguous. While emotions of compassion and happiness can encourage a positive attitude towards a certain message or product, the sense of loss can also result in negative evaluations due to undesired associations and moods (Holak and Havlena, 1998).

The number of studies on the influence of nostalgia proneness on consumer behavior is limited despite the knowledge that nostalgia has an important market potential. Nostalgic consumer behavior integrates both the brand attitude and purchasing intention (Cui, 2015). The aim of nostalgic advertising is to influence consumer behavior with the intention of establishing close relations by developing proper brand attitudes and purchasing intentions (Braun-LaTour et al. 2007). Brand attitude is a direct precursor of purchasing intention. Different from previous studies, it has been asserted in the present study that brand attitude and purchasing intention are probably affected positively from nostalgia tendency in addition to ad-evoked nostalgia. The fact that it has been carried out in Turkey, which is a developing country, is another authentic aspect of the study. Hence, the present study contributes to understanding the effectiveness of nostalgia marketing. When the popularity of nostalgic marketing strategies and their probability of making a positive impact on consumer behaviors are taken into consideration, it is observed that a limited number of studies in literature have examined nostalgia within the context of advertisements. For this reason, the present study may contribute to understanding 
nostalgia proneness and the effectiveness of ad-evoked nostalgia. The present study reviews the literature on nostalgia, develops a model for evaluating the influence of nostalgia proneness and ad-evoked nostalgia on purchase intention and tests that model. Moreover, a research suggestion is also presented that is worth examining in the future.

The effects of nostalgia proneness on ad-evoked nostalgia, brand attitude and purchase intention were tested in the present study via structural equation modeling (SEM). Having knowledge of these effects is important for enabling marketing managers to generate positive attitudes in consumers towards the brands in addition to developing effective and innovative strategies that will increase the purchase intentions of consumers.

\section{Literature Review and Hypothesis Development}

\section{Nostalgia and Nostalgia Proneness}

The word "nostalgia' is derived from "nostos" in Greek meaning "return to the past" and "algos" meaning "longing, desire or sorrow" and evokes feelings of longing for past memories (Hwang and Hyun, 2013). The concept of nostalgia as a fundamental aspect of the human condition has attracted the attention of many disciplines. Other eclectic approaches in history, psychology, sociology, anthropology, environmental psychology and social sciences can be considered among these (Holbrook, 1993). Previous studies in medicine and psychoanalytical literature set forth nostalgia as an indication of psychological distress and melancholia (Sarabi, 2012). The term nostalgia was first coined in 1688 by Johannes Hofer as part of a thesis on medicine for defining the excessive state of homesickness which was quite common among Swiss mercenaries fighting away from their home countries (Reisenwitz, 2001). From a psychiatric perspective, nostalgia is accepted as the longing for an idealized past known as screen memory in psychoanalysis rather than a longing for the past. It is not a real recreation of the past but the combination of many different memories and all negative emotions are filtered during this process (Hirsch, 1992). In consumer behavior literature, nostalgia is considered as part of the consumption preference for goods and experiences rather than a pathologic disorder (Goulding, 2001). Holbrook and Schindler (2003) describe nostalgia as "a choice toward things that were more common (people, places, etc.) when one was younger".

When considered from a marketing perspective, nostalgia is the personal emotion that is triggered by the experiences of the consumers and which effects their present product/service preferences (Hwang and Hyun, 2013). Based on definitions of nostalgia from different disciplines, the five perspectives of emotional, cognitive, attitudinal, behavioral and symbolic perspectives are very important for understanding the concept of nostalgia. The majority of the definitions of nostalgia emphasize one or more of these aforementioned dimensions. Each dimension has a specific role in defining nostalgia in marketing. However, the emotional 
and symbolic dimensions of nostalgia play a more important role in comparison with other dimensions when defining nostalgia in marketing. Accordingly, nostalgia in marketing can be defined as a positive feeling enacted by marketers through the use of nostalgic elements in the marketing mix.

Attitudes related with the past have the potential to influence consumer decisions and liking the past increases the chances of purchasing goods as an adult which were also purchased at younger ages (Sierra and McQuitty, 2007). However, even though it is not necessary to assume that the object of nostalgia is more frequent in the past, the relationship with the past creates a network of connection that is not present for other objects. These connections or relations generate a nostalgic response. Therefore, nostalgia can be conceptualized as a complex emotion, sense or mood generated with reflections from things related with the past (objects, people, experiences, ideas) (Holak and Havlena, 1998).

Measuring the nostalgia-proneness of an individual (the proneness for that individual to experience a nostalgic emotion) will enable the researchers to better define consumer marketing sections based on sensuality (Holak et al., 2006). Nostalgia proneness and the attitude towards advertising are two important factors that marketers use for predicting the reactions of consumers targeted for nostalgic marketing strategies (Cui, 2015).

Previous studies on consumer behavior and nostalgia have examined different cognitive and emotional factors. The studied cognitive variables are nostalgia proneness (Holbrook, 1993; Havlena and Holak, 1996; Reisenwitz et al., 2004; Holak et al., 2006; Seehuse et al., 2013), evoked nostalgia (Baker and Kennedy, 1994), longing for the past (Holbrook and Schindler, 1994; Schindler and Holbrook, 2003), attitudes towards advertisements and brands using nostalgic clues (Pascal et al., 2002; Muehling and Sprott, 2004; Sultan et al., 2010; Kessous and Roux, 2010; Muehling and Pascal, 2011; Bartier, 2011; Merchant and Rose, 2013; Ju et al., 2016) and the purchasing intent for nostalgic products (Rindfleisch et al., 2000; Sierra and McQuity, 2007). The examined emotional factors were nostalgia intensity for the past and related emotions (Holak and Havlena, 1992, 1998; Holbrook and Schindler, 2003; Barrett et al., 2010; Madoglou et al., 2017). The present study focuses on the impacts of nostalgia proneness on ad-evoked nostalgia, brand attitudes as well as purchase intention. The research model is shown in Figure 1. 


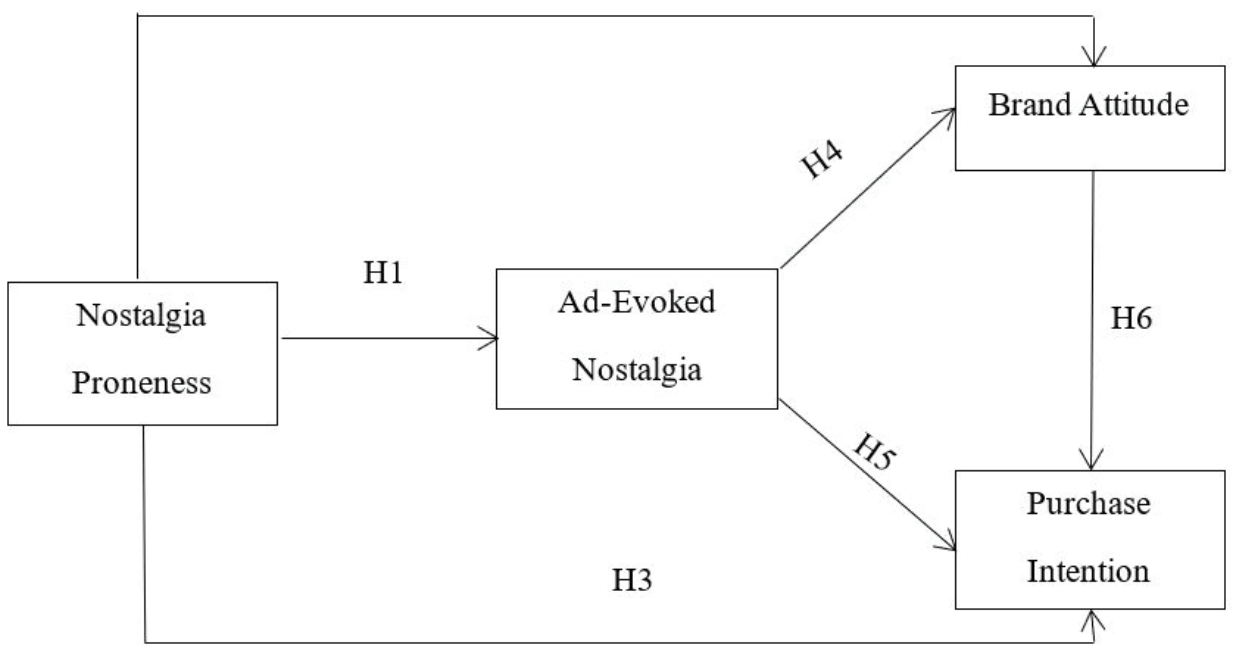

Figure 1. Proposed Model

This study attempts to determine the effect of nostalgia proneness on ad-evoked nostalgia. Studies have put forth that individuals are different with regard to their tendencies to experience nostalgic emotions (Holbrook, 1993). Therefore, nostalgia proneness shall positively affect the consumer's intensity of ad-evoked nostalgia. The intensity of nostalgia can be described as the strength of emotions related with the longing for a sterilized version of a previous time period (Stern, 1992). Reisenwitz et al. (2004) determined in their studies that the nostalgia proneness of consumers is related positively with both the advertisement and the nostalgia intensity towards the advertised brand. The following hypothesis has been put forth based on these opinions:

$\mathbf{H}_{1}$ : Nostalgia proneness has a significant effect on ad-evoked nostalgia.

Since nostalgia is usually conceptualized as a positive feeling or mood due to things connected with the past (Holak and Havlena, 1998), it is possible to expect that such positive emotions will make a positive contribution to the attitudes towards the advertised brand. Therefore, the following hypothesis has been developed.

$\mathbf{H}_{2}$ : Nostalgia proneness has a significant effect on the brand attitude.

Nostalgia marketing has a positive effect especially on the purchasing behavior of consumers (Nathasia and Nasution, 2016). For example, Lasaleta et al. (2014) found that when consumers feel nostalgic it decreases their desire for money and that they are willing to pay more for the products. Hence, nostalgia proneness may have a strong effect on the purchase 
intention of consumers. Expecting the nostalgia proneness will shape consumer preferences for products related with nostalgia, the following hypothesis was proposed:

$\mathbf{H}_{3}$ : Nostalgia proneness has a significant effect on purchase intention.

\section{Nostalgic Advertisements}

Nostalgia in marketing is defined as the positive nostalgic feeling instilled in consumers by way of using nostalgic elements in the marketing mix. The term nostalgia marketing is used for carrying out nostalgia related marketing activities in order to enliven the feelings of nostalgia and nostalgic memories of consumers leading to a desire for purchasing. Nostalgia based themes have recently attracted increasing attention among marketing and consumer behavior researchers as a common emotion for developing nostalgia based themes, free time activities and products (Holak et al., 2006). Nostalgia is generally conceptualized as an idealized appearance (Hirsch, 1992) of the past (be it lived or not) and it is almost always believed that the consumers are stimulated by way of positive emotions. That is why, the use of nostalgic themes in advertising is considered as a tool for generating positive reactions. For example, Burger King used classical music from the 1960's and 1970's in its TV advertisements in order to free itself from the chaotic fast-food environment (Pascal et al., 2002). The use of packaging for advertisement is another focus point in nostalgia marketing. For example, Coca-Cola sales increased in double digits after the company redesigned a similar plastic bottle in 1994 of its famous contour bottle (Reisenwitz et al., 2004). These examples support the opinion that nostalgia may be an effective tool with an impact on consumer behavior.

Based on the directedness of nostalgic elements, nostalgia marketing can be classified in two categories - visual and soft. While nostalgia advertising, logo design and store decoration etc. are among the primary methods of visual nostalgia marketing, evoking a sense of nostalgia in the consumer and retro branding are the two most common methods of soft nostalgia marketing. In addition, nostalgia marketing is not only adding a factor of nostalgia to the product; but it is also combining the business and products, finding nostalgic elements with brand potential for the products and using this factor to furnish the product brand with the meaning of appearance or characters (Cui, 2015). It is only in this way that nostalgic emotions can be instilled and encouraged more in consumers thereby leading to better sales results.

The basis of this study is the claim that nostalgic reactions generally consist of positive emotions and senses. Advertisers are of the opinion that nostalgia related stimuli (nostalgic words, pictures, music etc.) may evoke nostalgia in consumers hence leading to the development of a positive attitude with regard to their brands, products and purchasing intention. Results of previous studies (Pascal et al., 2002; Muehling and Sprott, 2004; Muehling and Pascal, 2011; Ju et al., 2016; Morgul, 2017) set forth that the senses evoked by an advertisement contribute to explaining the influences of the advertisement on consumer attitude and 
behavioral responses. Therefore, it was assumed in this study that advertisements leading to nostalgic reactions will contribute to making the brand be perceived better and thus result in increased sales probability, and the following hypotheses were developed:

$\mathbf{H}_{4}$ : Ad-evoked nostalgia has a significant effect on brand attitude.

$\mathbf{H}_{5}$ : Ad-evoked nostalgia has a significant effect on purchase intention.

The following hypothesis was developed since it was thought and observed in previous studies (Sierra and McQuity, 2007 and Ju et al., 2016) that nostalgic reactions and the attitude towards the brand shall have a statistically significant effect on the purchase intention towards the advertised product.

$\mathbf{H}_{6}$ : Brand attitude has a significant effect on purchase intention.

\section{Methodology}

\section{Sample and Data Collection}

The target audience of this research comprises of participants in Yalova aged 20 and above. Holbrook and Schindler (1991) reported in their studies that the sensitivity of the participants towards nostalgic emotions start generally around the age of 24. Based on this finding, the sample group was comprised of participants aged at least 20 who are living in Yalova. Data were acquired from participants via the survey method. The participants were first asked to answer the survey questions measuring their nostalgia proneness; afterwards they were asked to watch a 1990's advertisement of a food company that has been active in Turkey since 1973 after which participants were asked to answer the questions in the survey form. The study was carried out with TV advertisements since it has been put forth in various studies (e.g. Weibel et al., 2019) that TV advertisements have a greater instantaneous impact on consumers compared with social media advertisements and that they remain in the minds of consumers for longer periods of time.

Based on TUIK data, the total number of individuals aged 20 and above in Yalova is 182.994 people as of 2018. Since it was desired for the study sample group to represent the main body with regard to age criteria, the sample units were selected via quota sampling from among non-random sampling methods. The required number of questionnaires to be applied to each sample size and age group was determined based on the total population aged 20 and above at the Yalova province. In this context, the questionnaire was applied to 400 consumers and the number of data samples was 381 after clearing out the invalid data. The demographic profile of the participants can be observed in Table 1. 
Table 1

Demographic Profile of the Participants

\begin{tabular}{|c|c|c|c|c|c|}
\hline & f & $\%$ & & f & $\%$ \\
\hline Gender & & & Age & & \\
\hline Female & 173 & 45.4 & $20-29$ & 89 & 23.4 \\
\hline Male & 208 & 54.6 & $30-39$ & 61 & 16.0 \\
\hline Level of Education & & & $40-49$ & 71 & 18.6 \\
\hline Primary & 82 & 21.5 & $50-59$ & 70 & 18.4 \\
\hline Secondary & 79 & 20.7 & $60-69$ & 51 & 13.4 \\
\hline High school & 133 & 34.9 & $70+$ & 39 & 10.2 \\
\hline Upper secondary/ associate degree & 39 & 10.2 & Monthly household income & & \\
\hline Bachelor's degree & 43 & 11.3 & $2000 \mathrm{TRY}<$ & 70 & 18.4 \\
\hline Master's degree & 4 & 1.0 & 2001-4000 TRY & 149 & 39.1 \\
\hline \multirow[t]{4}{*}{ Doctorate } & 1 & 0.3 & 4001-6000 TRY & 74 & 19.4 \\
\hline & & & 6001-8000 TRY & 69 & 18.1 \\
\hline & & & 8001-10000 TRY & 18 & 4.7 \\
\hline & & & $10000 \mathrm{TRY}>$ & 1 & 0.3 \\
\hline Number of participants & & & & 381 & 100 \\
\hline
\end{tabular}

It can be seen when Table 1 is examined that majority of the participants are female, aged between 20-29, high school graduate and with a monthly family income of 2001-4000 TRY.

\section{Measurement Instruments and Analyses}

Nostalgia proneness was measured via the Southampton Nostalgia Scale by Barrett et al. (2010). Ad-evoked nostalgia was measured by the scale developed by Pascal et al. (2002). Brand attitude and purchase intention were measured by the scale proposed by Spears and Singh (2004).

In order to test the causal links mentioned in the research model, SEM was employed by using maximum likelihood estimation. SPSS 17 and AMOS 24 statistical packages were used to analyze the data.

\section{Results}

The Kruskal-Wallis test and Mann-Whitney $U$ test were applied in order to observe the influence of the demographic profile of the participants on their nostalgia proneness. Table 2 presents the results of the Kruskal-Wallis Test subject to age, education and family income. Table 3 presents the result of the Mann-Whitney U test subject to gender. 
Table 2

Kruskal-Wallis Test Results

\begin{tabular}{|c|c|c|c|c|c|}
\hline Variable & & Mean Ranks & Chi-Square & df & p \\
\hline \multirow[t]{6}{*}{ Age } & $20-29$ & 208.73 & \multirow{6}{*}{24.178} & \multirow{6}{*}{5} & \multirow{6}{*}{0.000} \\
\hline & $30-39$ & 220.97 & & & \\
\hline & $40-49$ & 176.83 & & & \\
\hline & $50-59$ & 140.35 & & & \\
\hline & $60-69$ & 199.57 & & & \\
\hline & $70+$ & 209.17 & & & \\
\hline \multirow[t]{7}{*}{ Level of Education } & Primary & 198.60 & \multirow{7}{*}{14.523} & \multirow{7}{*}{6} & \multirow{7}{*}{.024} \\
\hline & Secondary & 168.27 & & & \\
\hline & High school & 189.89 & & & \\
\hline & Upper secondary/ associate degree & 190.68 & & & \\
\hline & Bachelor's degree & 232.84 & & & \\
\hline & Master's degree & 122.00 & & & \\
\hline & Doctorate & 1.00 & & & \\
\hline \multirow[t]{6}{*}{ Household income } & 2000 TRY $<$ & 200.82 & \multirow{6}{*}{3.396} & \multirow{6}{*}{5} & \multirow{6}{*}{0.639} \\
\hline & 2001-4000 TRY & 180.40 & & & \\
\hline & 4001-6000 TRY & 194.51 & & & \\
\hline & 6001-8000 TRY & 198.80 & & & \\
\hline & 8001-10000 TRY & 190.00 & & & \\
\hline & $10000 \mathrm{TRY}>$ & 303.00 & & & \\
\hline
\end{tabular}

According to the values in Table 2, the difference between the nostalgia proneness of the participants is statistically significant with respect to the age and education level of the participants $(p<0.05)$. According to the Mean Ranks values; participants in the 30-39 age interval have higher nostalgia proneness compared with other participants. Similarly, participants with a bachelor's degree also have greater nostalgia proneness in comparison with the other participants.

Table 3

Mann-Whitney U Test Results

\begin{tabular}{lccc}
\hline Gender & Mean Rank & Z & p \\
\hline Female & 211.03 & -4.560 & .000 \\
Male & 160.38 & & \\
\hline
\end{tabular}

It was observed upon examining Table 3 that gender has a statistically significant impact on nostalgia proneness $(\mathrm{p}<0.05)$. The Mean Ranks values show that women have higher nostalgia proneness in comparison with men. This results supports the prevalent belief among marketing implementers, as well as the findings of researchers such as Holbrook (1993), Sedikides et al. (2015), Stern (1992) etc., that women tend to express their emotions more than men.

This study used SEM to test proposed hypotheses. Firstly, confirmatory factor analysis (CFA) was performed. The results obtained by CFA are as in Table 4 and Table 5. 
Table 4

Results of CFA

\begin{tabular}{|c|c|c|c|c|}
\hline Item wise constructs & $\begin{array}{l}\text { Standardized } \\
\text { loading }\end{array}$ & $\begin{array}{l}\text { Average variance } \\
\text { Extracted (AVE) }\end{array}$ & $\begin{array}{l}\text { Composite reli- } \\
\text { ability (CR) }\end{array}$ & $\begin{array}{l}\text { Cronbach's } \\
\text { alpha }\end{array}$ \\
\hline Nostalgia proneness & & 0.745 & 0.953 & 0.953 \\
\hline How valuable is nostalgia for you? & 0.856 & & & \\
\hline $\begin{array}{l}\text { How important is it for you to bring to } \\
\text { mind nostalgic experiences? }\end{array}$ & 0.891 & & & \\
\hline $\begin{array}{l}\text { How significant is it for you to feel } \\
\text { nostalgic? }\end{array}$ & 0.881 & & & \\
\hline How prone are you to feeling nostalgic? & 0.932 & & & \\
\hline How often do you experience nostalgia? & 0.839 & & & \\
\hline $\begin{array}{l}\text { Generally speaking, how often do you } \\
\text { bring to mind nostalgic experiences? }\end{array}$ & 0.858 & & & \\
\hline $\begin{array}{l}\text { Specifically, how often do you bring to } \\
\text { mind nostalgic experiences? }\end{array}$ & 0.775 & & & \\
\hline Evoked nostalgia & & 0.759 & 0.969 & 0.967 \\
\hline Reminds me of the past. & 0.841 & & & \\
\hline Helps me recall pleasant memories. & 0.874 & & & \\
\hline Makes me feel nostalgic. & 0.858 & & & \\
\hline $\begin{array}{l}\text { Makes me reminisce about a previous } \\
\text { time. }\end{array}$ & 0.851 & & & \\
\hline $\begin{array}{l}\text { Makes me think about when I was } \\
\text { younger. }\end{array}$ & 0.818 & & & \\
\hline Evokes fond memories. & 0.864 & & & \\
\hline Is a pleasant reminder of the past. & 0.896 & & & \\
\hline $\begin{array}{l}\text { Brings back memories of good times } \\
\text { from the past. }\end{array}$ & 0.910 & & & \\
\hline Reminds me of the good old days. & 0.905 & & & \\
\hline Reminds me of good times in the past. & 0.892 & & & \\
\hline Brand attitude & & 0.823 & 0.959 & 0.955 \\
\hline Unappealing/appealing & 0.881 & & & \\
\hline Bad/good & 0.913 & & & \\
\hline Unpleasant/pleasant & 0.933 & & & \\
\hline Unfavorable/favorable & 0.936 & & & \\
\hline Unlikeable/likeable & 0.872 & & & \\
\hline Purchase intention & & 0.821 & 0.948 & 0.947 \\
\hline $\begin{array}{l}\text { Definitely do not intend to buy/definitely } \\
\text { intend }\end{array}$ & 0.913 & & & \\
\hline Very low/high purchase interest & 0.902 & & & \\
\hline Definitely not buy it/definitely buy it & 0.909 & & & \\
\hline Probably not/probably buy it & 0.901 & & & \\
\hline
\end{tabular}

The results in Table 4 show the standardized regression coefficients $(\lambda)$ indicating the relationship between items and the related structure, AVE, CR and Cronbach $\alpha$ values. Since standardized regression coefficients represent the correlation coefficient, they may be considered to be quite high. It can be seen from Table 4 that Cronbach $\alpha$ and CR values are above the 0.70 (Hair et al., 2012) and are at acceptable levels. 
Table 5

Fit Indexes for the Research Model

\begin{tabular}{lcc}
\hline Fit Indexes & Calculated Value & Suggested Value \\
\hline$\chi^{2} / \mathrm{df}$ & 2.288 & $\leq 5$ \\
GFI & 0.884 & $\geq 0.8$ \\
AGFI & 0.855 & $\geq 0.8$ \\
CFI & 0.970 & $\geq 0.9$ \\
TLI & 0.965 & $\geq 0.9$ \\
IFI & 0.970 & $\geq 0.9$ \\
RMSEA & 0.059 & $\leq 0.08$ \\
\hline
\end{tabular}

The fit indexes for the model are given in Table 5. The findings indicate that the model satisfactorily fits the data. Construct validity was evaluated via convergent and discriminant validity. As can be seen from Table 4, the AVE values of all factors were above 0.50 while the composite reliability values were determined above 0.70 (Hair et al., 2012). The AVE value calculated for each factor should be greater than the square of the correlations of each factor with other factors in order to ensure discriminant validity for the factors (Fornell and Larcker, 1981). Table 6 presents the correlation table for reliability measurements and discriminant validity. As can be seen, it is possible to indicate that discriminant validity has been attained since the AVE values for each factor are greater than the highest square of correlations between factors.

Table 6

Discriminant Validity and Correlation between Constructs

\begin{tabular}{lccccccc}
\hline Factor & CR & AVE & MSV & BA & NP & EN & PI \\
\hline BA & 0.959 & 0.823 & 0.699 & 0.907 & & & \\
NP & 0.953 & 0.745 & 0.536 & 0.610 & 0.863 & & \\
EN & 0.969 & 0.759 & 0.536 & 0.707 & 0.732 & 0.871 & \\
PI & 0.948 & 0.821 & 0.699 & 0.836 & 0.586 & 0.634 & 0.906 \\
\hline
\end{tabular}

We tested the research hypotheses with the aid of structural equation modelling using Amos 24. The structural model is shown in Figure 2. The findings of hypothesis tests are shown in Table 7.

Table 7

SEM Results

\begin{tabular}{|c|c|c|c|c|}
\hline \multicolumn{2}{|c|}{ Hypotheses } & \multirow{2}{*}{$\begin{array}{c}\text { Estimates } \\
0.751\end{array}$} & \multirow{2}{*}{$\begin{array}{c}\text { CR } \\
15.195\end{array}$} & \multirow{2}{*}{$\frac{\text { Sig. }(\mathbf{p}<\mathbf{0 . 0 5})}{* * *}$} \\
\hline H1 & Nostalgia proneness $\bigotimes$ Ad-evoked nostalgia & & & \\
\hline $\mathrm{H} 2$ & Nostalgia proneness $\bigotimes$ Brand attitude & 0.211 & 3.285 & 0.001 \\
\hline $\mathrm{H} 3$ & Nostalgia proneness $\bigotimes$ Purchase intention & 0.122 & 2.210 & 0.027 \\
\hline $\mathrm{H} 4$ & Ad-evoked nostalgia $\mathbb{B}$ Brand attitude & 0.585 & 8.935 & $* * *$ \\
\hline H5 & Ad-evoked nostalgia冈Purchase intention & 0.020 & 0.335 & 0.738 \\
\hline H6 & Brand attitude『Purchase intention & 0.773 & 13.909 & $* * *$ \\
\hline
\end{tabular}




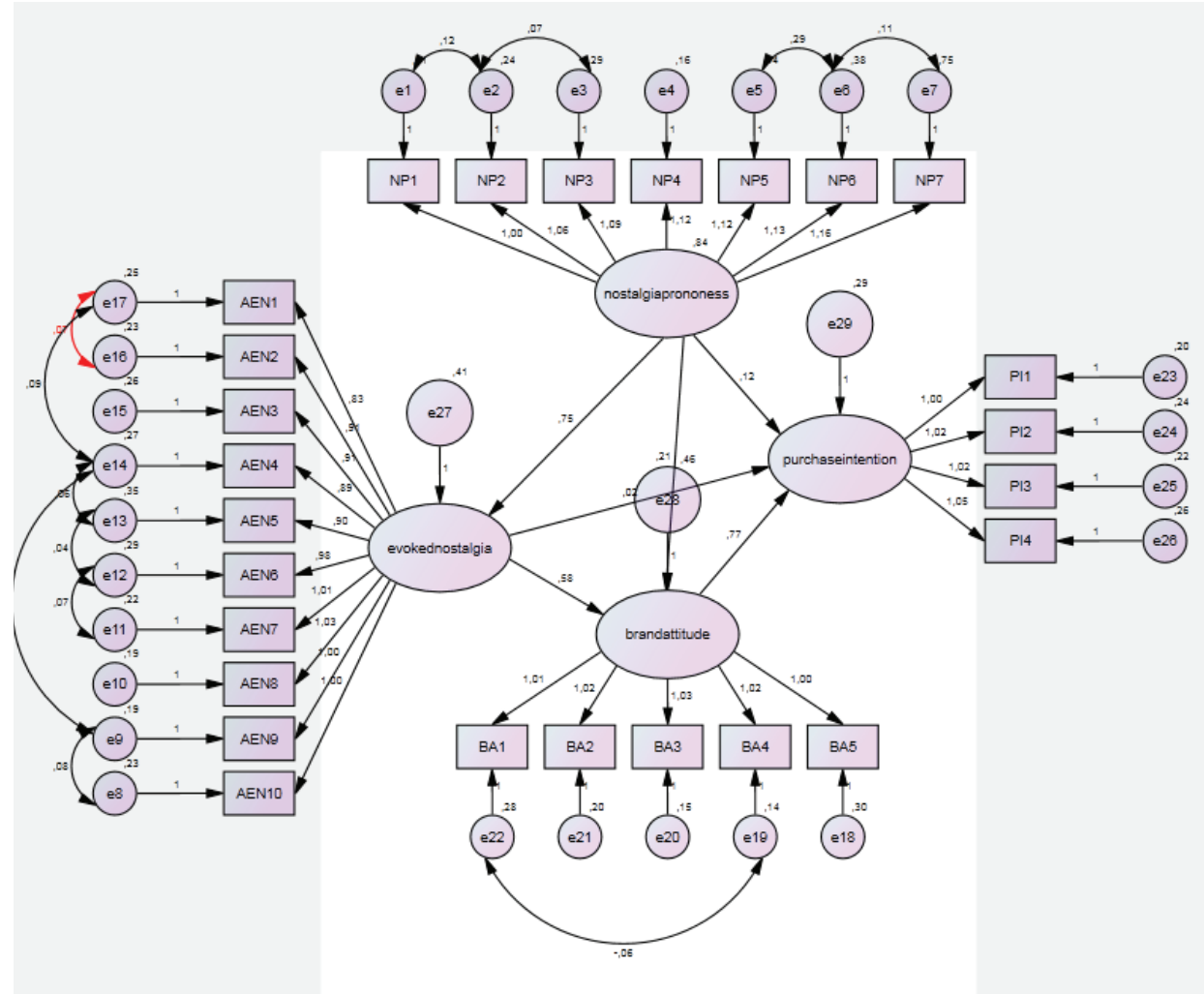

Figure 2. Structural Model

The study results indicate that nostalgia proneness has a strong effect on ad-evoked nostalgia $(\beta=0.751 ; \mathrm{p}<.05)$. Hence, $\mathrm{H} 1$ is supported. Moreover, it was also assumed that nostalgia proneness has a significant effect on the brand attitude (H2) and purchase intention (H3). The results point out that the effects of nostalgia proneness are statistically significant for both the brand attitude and the purchase intention. Thus, $\mathrm{H} 2(\beta=0.211 ; \mathrm{p}<.05)$ and $\mathrm{H} 3(\beta=0.122 ; \mathrm{p}>$ $.05)$ are supported.

It was found that ad-evoked nostalgia has a significant effect on the brand attitude (H4) and purchase intention (H5). The results show that ad-evoked nostalgia has a significant effect on the brand attitude but that its effects on purchase intention are not statistically significant. Therefore, $\mathrm{H} 4(\beta=0.585 ; \mathrm{p}<.05)$ is supported, however $\mathrm{H} 5(\beta=0.02 ; \mathrm{p}>.05)$ is not supported.

H6 states that the attitude towards the brand will have an effect on the purchase intention of participants. The study results put forth that the attitude towards the brand has a strong effect on purchase intention $(\beta=0.773 ; p<.05)$. Thus, H6 is supported. 


\section{Conclusion and Discussion}

The present research aimed to investigate the effect of nostalgia proneness and ad-evoked nostalgia on the brand attitude and purchase intention. The responses acquired from participants in Yalova were analyzed using SEM.

As a result of the research, it was found that nostalgia proneness has a positive effect on nostalgia for advertisements, parallel to the findings by Reisenwitz et al. (2004) and Morgul (2017). Accordingly, consumers with a high level of proneness to being nostalgic will have stronger feelings towards nostalgic advertisements. It was also determined that in addition to the nostalgia proneness evoked by advertisements; nostalgia proneness has a positive effect on the brand attitude and purchase intention as well.

Parallel to the findings by Pascal et al. (2002), Muehling and Sprott (2004), Muehling and Pascal (2012), Ju et al. (2016), Morgul (2017), the results of the present study point out that while advertisements that result in nostalgic reactions may contribute to positive perceptions regarding the advertised brand, it may not have sufficient direct impact on the probability of the product being purchased more. Contrary to the results of Pascal et al. (2002), the result that the ad-evoked nostalgia has no effect on purchase intention was parallel to the findings of the study by Ju et al. (2016). The fact that the sense of nostalgia evoked will not have sufficient effect on purchase intention because it is short lived may be put forth as a probable reason for this result. However, similar to the findings in literature by Sierra and McQuity (2007) and Ju et al. (2016), it was observed that brand attitude is the variable with the strongest effect on purchase intention.

The findings mean that nostalgia can be a strong tool for advertisers/marketers. Hence, it may be beneficial for advertisers to use the advertisement themes for enacting the desired emotional response (positive brand attitudes) to stimulate a sense of nostalgia. In accordance with the marketing/advertisement literature, the findings of the present research provide an additional support as a theoretical and practical structure that explains the impacts of nostalgia on advertising.

The results of the present study support the current use of nostalgia based advertising themes for companies from an administrative perspective. The findings put forth prooves that ad-evoked emotions may have a positive effect on the brand attitude. This is a very important finding for advertisers and indicates that using nostalgic themes to draw attention and to establish connection with the targeted audience will be more efficient for attainment of their objectives.

Today, marketers have realized that nostalgia is effective for many consumers and that it has become an indispensable part of the marketing efforts for many companies. Marketers 
can use the influence of nostalgic marketing on consumers in order to put forth a comprehensive marketing message. Hence, the perceptions on the marketed brand and its products may be improved and purchase intention for the advertised nostalgic product may be increased. The results of the study support the opinion that nostalgia may lead to consumers to "develop a longing for the past" in addition to make them feel the "desire to purchase the products of the advertisers". In conclusion, marketing budgets of businesses will be spent more effectively and it will become a valuable strategy for increasing or earning market share.

Even though the economies of the world and the Turkish economy have undergone various and multidimensional crises in the past, today for the first time, they are all experiencing a significant economic problem that does not result from the internal dynamics of economy and that includes within it the fear of death as the determining factor. An economic crisis ensued in all countries following the Covid-19 pandemic and the majority of small-mid sized businesses have been closed. As a result, unemployment statistics reached a peak point in our country and in the world. The IMF revised the growth expectation of Turkey for the year 2020 from $3.0 \%$ to $5.0 \%$ recession expectation (Karakaya, 2020). The fact that tourism almost came to a halt in Turkey during the pandemic coupled with the decrease in exports prevented the entry of foreign currency into the country which resulted in an increase in the exchange rates leading to a major decrease in the value of Turkish Lira.

The buying behaviors of consumers also varied rapidly during the Covid-19 pandemic. While consumers were able to give more rational decisions prior to the pandemic, the factors of panic, fear and uncertainty of the future due to the pandemic made a psychological impact on consumers. When used properly during this period, nostalgic marketing activities presented the businesses with opportunities that provide earning potential due to the increase in the longing for the past during this period and thus provided a possibility to establish a loyal and sustainable consumer base. This was because during this period, consumers reduced their demands for goods outside of necessity goods while continuing to purchase the brands and products they used and trusted in the past instead of trying out new ones. In addition, internet sales increased significantly during this period due to isolation and staying at home. Even people who avoided shopping online previously have started to meet their needs online. This will most likely have a significant impact on retail sales. Basha et al. (2020) carried out a study as a result of which they put forth that the social media platform is the best platform for companies to market their products and services during the covid19 pandemic and that the companies may use this platform to present new offers to their customers and to establish a brand image. Hence, it seems that sales and marketing will evolve into direct marketing and distant sales in the future. 


\section{Future Research and Limitations of the Study}

First of all, it is important to carry out more studies to understand the impacts of nostalgia on consumer reactions. This study is limited only to the TV advertisements of a well-known brand in Turkey being displayed to viewers. It is not certain whether similar findings will be obtained for unknown (new) brands in different environments. Another limitation of the study is that purchase intention has been used as the dependent variable. The purchase intention of consumers does nor always result in actual purchase behavior. Actual purchase behavior should be studied in future studies.

Moreover, the study was limited only with consumers residing in the province of Yalova in Turkey. The fact that the data acquired in the study have been collected via the quota sampling method from among non-random sampling methods also limits the generalizability of the results. Attempts to overcome this were made by ensuring that the required sample group had the same ratio as that of the main body.

Peer-review: Externally peer-reviewed.

Conflict of Interest: The authors have no conflict of interest to declare.

Grant Support: The authors declared that this study has received no financial support.

\section{References}

Baker, S. M, \& Kennedy, P. F. (1994). Death by nostalgia: a diagnosis of context specific cases. Advances in Consumer Research, 21,169-174.

Barrett, F. S., Grimm, K. J., Robins, R.W., Wildschut, T., Sedikides, C., \& Janata, P. (2010). Music-evoked nostalgia: affect, memory, and personality. Emotion, 10(3), 390-403.

Bartier, A. L. (2011). Things were better before: what is the power of nostalgia toward the brand?. Louvain School of Management Working Paper Series 11, 1-22.

Basha, A., Parthasarathi, S. K., \& Aktharsha, U.S. (2020). A study on impact of COVID-19 pandemic on consumer buying behavior in Bangalore City. Journal of Emerging Technologies and Innovative Research (JETIR), 7(4), 1396-1404.

Braun-LaTour, K. A., LaTour, M.S., \& Zinkhan, G.M. (2007). Using childhood memories to gain insight into brand meaning. Journal of Marketing, 71(2), 45-60.

Cui, R. (2015). A Review of Nostalgic Marketing. Journal of Service Science and Management, 8, 125-131.

Fornell, C., \& Larcker, D.D.F. (1981). Evaluating structural equation models with unobservable variables and measurement error. Journal of Marketing Research, 18(1), 39-50.

Goulding, C. (2001). Romancing the past: heritage visiting and the nostalgic consumer. Psychology and Marketing, 18(6), 565-592.

Hair, J. F., Black, W.C., Babin, B.J., Anderson, R.E., \& Tatham, R.L. (2012). Multivariate data analysis, New Delhi: Pearson Publications.

Havlena, W. J., \& Holak, S.L. (1996). Exploring nostalgia imagery through the use of consumer collages. Advances in Consumer Research, 23, 35-42. 
Hirsch, A. R. (1992). Nostalgia: a neuropsychiatric understanding. Advances in Consumer Research, 19, 390-395.

Holak, S. L., \& Havlena, W.J. (1992). Nostalgia: an exploratory study of themes and emotions in the nostalgic experience. Advances in Consumer Research, 19, 380-387.

Holak, S. L., \& Havlena, W. J. (1998). Feelings, fantasies, and memories: an examination of the emotional components of nostalgia. Journal of Business Research, 42, 217-226.

Holak, S. L., Havlena, W. J., \& Matveev, A.V. (2006). Exploring nostalgia in russia: testing the index of nostalgia-proneness. European Advances in Consumer Research, 7, 195-200.

Holbrook, M. B., \& Schindler, R.M. (1989). Some exploratory findings on the development of musical tastes. Journal of Consumer Research, 16, 119-124.

Holbrook, M. B., \& Schindler R.M. (1991). Echoes of the dear departed past: some work in progress on nostalgia. Advances in Consumer Research, 18, 330-33.

Holbrook, M. B. (1993). Nostalgia and consumption preferences: some emerging patterns of consumer tastes. Journal of Consumer Research, 20, 245-256.

Holbrook, M. B., \& Schindler, R.M. (1994). Age, sex, and attitude toward the past as predictors of consumers' aesthetic tastes for cultural products. Journal of Marketing Research, 31(3), 412-422.

Holbrook, M. B., \& Schindler, R.M. (1996). Market segmentation based on age and attitude toward the past: concepts, methods, and findings concerning nostalgic influences on customer tastes. Journal of Business Research, 37, 27-39.

Holbrook, M. B., \& Schindler, R.M. (2003). Nostalgic bonding: exploring the role of nostalgia in the consumption experience. Journal of Consumer Behavior, 3(2), 107-127.

Hwang, J., \& Hyun, S.S. (2013). The impact of nostalgia triggers on emotional responses and revisit intentions in luxury restaurants: the moderating role of hiatus. International Journal of Hospitality Management, 33, 250-262.

IMF. (April 2020). "World Economic Outlook", The Great Lockdown. IMF. https://www.imf.org/en/publications/WEO/issues/2020/04/14/Weo-April-2020 (Erişim Tarihi: 03.09.2020)

Ju, I., Kım, J., Chang, M. J., \& Bluck, S. (2016). Nostalgic marketing, perceived self-continuity, and consumer decisions. Management Decision, 54(8), 2063-2083.

Kessous, A., \& Roux, E. (2010). Brands considered as "nostalgic"; consequences on attitudes and consumer-brand relationships. Recherce et Applications en Marketing, 25(3), 29-55.

Lasaleta, J. D., Sedikides, C., \& Vohs, K. D. (2014). Nostalgia weakens the desire for money. Journal of Consumer Research, 41(3), 713-729.

Lefi, L., \& Gharbi, A. (2011). Nostalgia and brand attachment: theoretical framework and application in the case of a tunisian advertising. Journal of Business Studies Quarterly, 3(1), 187-200.

Madoglou, A., Gkinopoulos, T., Xanthopoulos, P., \& Kalamaras, D. (2017). Representations of autobiographical nostalgic memories: generational effect, gender, nostalgia proneness and communication of nostalgic experiences. The Journal of Integrated Social Sciences, 7(1), 60-88.

Merchant, A., \& Rose, G.M. (2013). Effects of advertising-evoked vicarious nostalgia on brand heritage. Journal of Business Research, 66(12), 2619-2625.

Morgül, E. (2017). Effects of nostalgia advertising on brand attitude: an example from turkey. Journal of Current Researches on Social Sciences, 7(4), 1-12. 
Muehling, D. D., \& Sprott, D.E. (2004). The power of reflection: an empirical examination of nostalgia advertising effects. Journal of Advertising, 33(3), 25-35.

Muehling, D. D., \& Pascal, V.J. (2011). An empirical investigation of the differential effects of personal, historical, and non-nostalgic advertising on consumer responses. Journal of Advertising, 40(2), 107-122.

Nathasia, E., \& Nasution, R.A. (2016). The effect of nostalgia marketing towards advertising engagement (aqua case). Journal of Business and Management, 5(4), 566-580.

Pascal, V. J., Sprott, D.E., \& Muehling, D.D. (2002). The influence of evoked nostalgia on consumers' responses to advertising: an exploratory study. Journal of Current Issues and Research in Advertising, 24(1), 39-49.

Reisenwitz, T. H. (2001). Nostalgia advertising: an exploratory study of its effectiveness and the effect of nostalgia proneness. Phd Dissertation, Cleveland State University, A.B.D.

Reisenwitz, T. H, Iyer, R., \& Cutler, B. (2004). Nostalgia advertising and the influence of nostalgia proneness. The Marketing Management Journal, 14(2), 55- 66.

Rindfleisch, A., Freeman, D., \& Burroughs, J.E. (2000). Nostalgia, materialism, and product preference: an initial inquiry. Advances in Consumer Research, 27, 36-41.

Sarabi, S. (2012). The influence of nostalgia on acculturative stress in first generation iranians in the united states. Phd Dissertation, Wright Institute Graduate School of Psychology, Berkeley, CA.

Schindler, R. M., \& Holbrook, M.B. (2003). Nostalgia for early experience as a determinant of consumer preferences. Psychology \& Marketing, 20(4), 275-302.

Sedikides, C., Wildschut, T., Routledge, C., Arndt, J., Hepper, E.G., \& Zhou, X. (2015). To nostalgize: Mixing memory with affect and desire. Advances in Experimental Social Psychology, 51, 189-273.

Seehusen, J., Cordaro, F., Wildschut, T., Sedikides, C., Routledge, C., Blackhart, G.C., Epstude, K., \& Vingerhoets, A. J. J. M. (2013). Individual differences in nostalgia proneness: the integrating role of the need to belong. Personality and Individual Differences, 55, 904-908.

Sierra, J. J., \& McQuitty, S. (2007). Attitudes and emotions as determinants of nostalgia purchases: an application of social identity theory. Journal of Marketing Theory and Practice, 15(2), 99-112.

Spears, N., \& Singh, S.N. (2004). Measuring attitude toward the brand and purchase intentions. Journal of Current Issues and Research in Advertising, 26(2), 53-66.

Stern, B. B. (1992). Historical and personal nostalgia in advertising text: the fin de siecle effect. Journal of Advertising, 21(4), 11-22.

Sultan, A. J, Muehling, D., \& Sprott, D.E. (2010). The effect of personal attachment and usage on consumers' response to nostalgia. Proceedings of the Academy of Marketing Studies, 15(2), 1-3.

Weibel, D., Francesco, R., Kopf, R., Fahrni, S., Brunner, A., Kronenberg, P., Lobmaier, J.S., Reber, T.P., Mast, F.W., \& Wissmath, B. (2019). TV vs. youTube: TV advertisements capture more visual attention, create more positive emotions and have a stronger impact on implicit long-term memory. Frontiers in Psychology, 10, 1-9. 